\title{
Enantioselective Reduction of Trifluoromethyl Ketones with Chiral Organomagnesium Amides (COMAs)
}

\author{
Kelvin H. Yong and J. Michael Chong* \\ Guelph-Waterloo Centre for Graduate Work in Chemistry and Biochemistry, $(G W C)^{2}$ \\ Department of Chemistry, University of Waterloo, Waterloo, Ontario, Canada \\ N2L $3 G 1$
}

\section{Supporting Information}

\section{A. General Experimental}

All reactions were performed using flame-dried glassware under an argon atmosphere. Diethyl ether and THF were freshly distilled from $\mathrm{Na} /$ benzophenone. ${ }^{1} \mathrm{H}$ and

${ }^{13} \mathrm{C}$ NMR spectra were recorded in $\mathrm{CDCl}_{3}$ at 300 and $75 \mathrm{MHz}$, respectively. Optical rotations were recorded in cells with $10 \mathrm{~cm}$ path length on a Perkin-Elmer 241 digital polarimeter. The known diamine $1 \mathbf{a}^{1}$ was prepared from $(R)$-phenylglycine and diamines $\mathbf{1 b},^{2} \mathbf{1 c},^{3} \mathbf{1 d},^{4} \mathbf{1 e},^{4} \mathbf{1 f},^{5} \mathbf{1 g},^{3}$ and $\mathbf{1 h}^{3}$ were prepared from $(R)-2$-phenyl-2-(1piperidinyl)ethanol ${ }^{5}$ as previously described. Enantiomeric ratios of the carbinols were determined either directly or indirectly (as benzoate) by HPLC using a $4.6 \mathrm{~mm}$ x $150 \mathrm{~mm}$ Chiralcel OD column, eluting with 5-10\% isopropanol in hexanes or $100 \%$ hexanes (for benzoate).

Trifluoromethyl ketones were prepared according to procedures described previously.

\footnotetext{
1 Rossiter, B. E.; Eguchi, M.; Hernandez, A. E.; Vickers, D.; Medich, J.; Marr, J.; Heinis, D. Tetrahedron Lett. 1991, 32, 3973-3976.

2 Rossiter, B. E.; Eguchi, M.; Miao, G.; Swingle, N. M.; Hernandez, A. E.; Tetrahedron, 1993, 49, $965-986$.

3 Curthbertson, E.; O’Brien, P.; Towers, T. D. Synthesis, 2001, 693-695.

4 Saraavanan, P.; Singh, V. K. Tetrahedron Lett. 1998, 39, 167-170.

5 Sousa, S. E.; O'Brien, P.; Poumellec, P. J. Chem. Soc., Perkin Trans. 1 1998, 1483-1492.

6 a) Chong, J. M.; Mar, E. K. J. Org. Chem. 1991, 56, 893-896; b) Mar, E. K. Ph. D. Dissertation, Ch. 6, University of Waterloo, 1990.
} 
Chiral carbinols $\mathbf{3 a}, \mathbf{3 b}, \mathbf{3 c}, \mathbf{3 d}$ and $\mathbf{3 e}$ were reported by our laboratory previously. ${ }^{6}$ Chiral carbinol 3f was reported by Brown. ${ }^{8}$

\section{Preparation of diisopropylmagnesium solution. ${ }^{9}$}

1,4-Dioxane (18 mL, 0.22 mole) was added slowly to a mechanically stirred $1 \mathrm{M}$ solution of $i$-propylmagnesium chloride $(200 \mathrm{~mL}, 0.2 \mathrm{~mole})$. The resultant heterogeneous mixture was stirred at ambient temperature overnight (8-12 h). The suspension was then transferred via cannula to centrifuge tubes and centrifuged $(2500 \mathrm{rpm}, 30 \mathrm{~min})$ to give a clear and colorless diisopropylmagnesium solution. A few drops of 1,4-dioxane were added to the solution to confirm the complete precipitation of magnesium dichloride, and the clear supernatant was then transferred via cannula into a Schlenk tube and the concentration was determined by titration before use.

\section{Titration of dialkylmagnesium solution.}

The following procedure is an extension of the titration procedure reported by Love $^{10}$ for Grignard reagents. The dialkylmagnesium solution $(\sim 0.5 \mathrm{M})$ was added dropwise to a stirred solution of accurately weigh salicylaldehyde phenylhydrazone $(\sim 1$ mmol) in THF (15 mL) under argon at room temperature. The solution turned yellow initially and the end point is indicated by the bright golden orange color. The exact amount of dialkylmagnesium solution needed to reach the end point was recorded. Each mole of

\footnotetext{
${ }^{7}$ Linderman, R. J.; Lonikar, M. S. J. Org. Chem. 1988, 53, 6013-6022.

${ }^{8}$ Ramachandran, P. V.; Teodorović, A. V.; Gong, B.; Brown, H. C. Tetrahedron: Asymmetry 1994, 5, 1061 1074.

9 Wakefield, B. J. "Organomagnesium Methods in Organic Synthesis" Academic Press, 1995, 65-67.

${ }^{10}$ Love, B. E.; Jones, E. G. J. Org. Chem. 1999, 64, 3755-3756.
} 
dialkylmagnesium will react with two moles of indicator and the concentration was calculated by:

$$
\left.\mathrm{M}=\mathrm{mmol} \text { of indicator / (2 } \mathrm{x} \text { volume of } \mathrm{R}_{2} \mathrm{Mg} \text { in } \mathrm{mL}\right)
$$

\section{Preparation of $i$-Pr-COMA (2) solution using ligand 1f.}

A solution of $0.52 \mathrm{M} i-\operatorname{Pr}_{2} \mathrm{Mg}(0.95 \mathrm{~mL}, 0.494 \mathrm{mmol})$ was added to a solution of precooled $\left(-78{ }^{\circ} \mathrm{C}\right)$ diamine $\mathbf{1 f}(150 \mathrm{mg}, 0.51 \mathrm{mmol})$ in ether $(12 \mathrm{~mL})$ under argon. The resultant solution was then stirred at ambient temperature for $0.5 \mathrm{~h}$ to form a cloudy solution. Then THF $(1.5 \mathrm{~mL})$ was added to the reaction and stirred for $0.5 \mathrm{~h}$ to form the a clear $i$-Pr-COMA reagent. The resultant COMA solution was used directly in the next reaction.

\section{B. COMA for Enantioselective MPV Reductions}

\section{2,2,2-Trifluoro-1-phenylethanol (3a)}

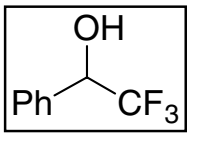

Carbinol 3a was prepared using a number of different COMAs and the yields and er are shown in Table 2. The following is a typical procedure used for enantioselective reduction of ketones:

The $i$-Pr-COMA solution $\left(0.5 \mathrm{mmol}\right.$ ) (from $i$ - $\mathrm{Pr}_{2} \mathrm{Mg}$ and diamine 1e) was cooled to $-78{ }^{\circ} \mathrm{C}$ and a solution of trifluoromethyl acetophenone $(44 \mathrm{mg}, 0.25 \mathrm{mmol})$ in ether $(1 \mathrm{~mL})$ was added and the reaction was stirred at $-78{ }^{\circ} \mathrm{C}$ and allowed to warm up to rt slowly (5-6 h). The reaction was quenched with saturated aqueous $\mathrm{NH}_{4} \mathrm{Cl}(5 \mathrm{~mL})$ and the layers were separated. The aqueous phase was extracted with ether $(3 \times 10 \mathrm{~mL})$ and the combined 
organic phase was washed with $0.5 \mathrm{M} \mathrm{HCl}$ to remove the diamine $\mathbf{1 f}(2 \mathrm{x} 3 \mathrm{~mL})$. The diamine can be recovered by acid-base extraction (see below). The organic phase was dried $\left(\mathrm{Na}_{2} \mathrm{SO}_{4}\right)$, filtered and concentrated under reduced pressure to give the crude $\mathbf{3 a}$. The product was purified by silica gel column chromatography $\left(10 \% \mathrm{Et}_{2} \mathrm{O}\right.$ in hexanes) to give the desired alcohol as a pale yellow oil $(40 \mathrm{mg}, 89 \%$, er $=13: 87)$. The enantiomeric ratio of the product was determined by chiral phase HPLC (ChiralCel-OD, 5\% isopropanol in hexanes, $1.0 \mathrm{~mL} / \mathrm{min} S: 25.3 \mathrm{~min}, R: 27.0 \mathrm{~min}) .[\alpha]_{\mathrm{D}}{ }^{25}=+21.6\left(\mathrm{c}=0.52, \mathrm{CHCl}_{3}\right)$; Lit. $^{11}(S-$ isomer $),[\alpha]_{\mathrm{D}}{ }^{25}=+30.4\left(\mathrm{c}=1.56, \mathrm{CHCl}_{3}\right) .{ }^{1} \mathrm{H} \mathrm{NMR}\left(300 \mathrm{MHz}, \mathrm{CDCl}_{3}\right) \delta 7.5-7.3(5 \mathrm{H}, \mathrm{m})$, $4.99(1 \mathrm{H}$, br q, $J=6.1 \mathrm{~Hz}), 2.74(1 \mathrm{H}$, br s$) ;{ }^{13} \mathrm{C} \mathrm{NMR}\left(75 \mathrm{MHz}, \mathrm{CDCl}_{3}\right)$ 8134.0, 129.7, $128.7,127.5,124.3\left(\mathrm{q}, J_{C-F}=282 \mathrm{~Hz}\right), 74.6\left(\mathrm{q}, J_{C-F}=32.0 \mathrm{~Hz}\right)$; MS (EI) $m / z 176\left(\mathrm{M}^{+}, 31\right)$, 107 (100), 79 (84).

$\underline{\text { Recovery of diamine : }}$

The acidic aqueous phase was washed once with ether $(1 \mathrm{~mL})$, then basified with 5 $\mathrm{M} \mathrm{KOH}$. The diamine was then extracted into ether $(3 \times 5 \mathrm{~mL})$. The organic layer was dried $\left(\mathrm{Na}_{2} \mathrm{SO}_{4}\right)$, filtered and evaporated under reduced pressure to give a light yellow oil. Kugelrohr distillation $(0.5 \mathrm{~mm} \mathrm{Hg})$ gave the recovered amine as colorless oil $(\sim 80 \%$ recovery).

\section{2,2,2-Trifluoro-1-(1-naphthyl)ethanol (3b)}

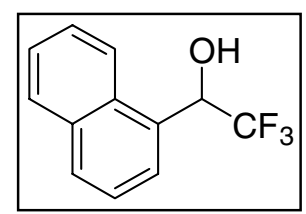

and the yields and er are shown in Table 2. The following represents the data for one of the reactions.

\footnotetext{
${ }^{11}$ Matsuda, T.; Harada, T.; Nakajima, N.; Itoh, T.; Nakamura, K. J. Org. Chem. 2000, 65, 157-163.
} 
Carbinol 3b was prepared using $i$-Pr-COMA $\left(0.5 \mathrm{mmol}\right.$ ) (from $i$ - $\mathrm{Pr}_{2} \mathrm{Mg}$ and diamine 1f) and the corresponding trifluoromethyl ketone $(58 \mathrm{mg}, 0.26 \mathrm{mmol})$. The product was purified by silica gel column chromatography $\left(10 \rightarrow 20 \% \mathrm{Et}_{2} \mathrm{O}\right.$ in hexanes) to give $\mathbf{3 b}$ as a colourless oil ( $56 \mathrm{mg}, 96 \%$, er $=7: 93$ ). The enantiomeric ratio of the product was determined by chiral phase HPLC (ChiralCel-OD, 10\% isopropanol in hexanes, 1.0 $\mathrm{mL} / \mathrm{min} R: 10.4 \mathrm{~min}, S: 35.9 \mathrm{~min}) .[\alpha]_{\mathrm{D}}{ }^{25}=+17.5(\mathrm{c}=1.01$, EtOH $) ;$ Lit. $^{12}(R$-isomer $)$, $[\alpha]_{\mathrm{D}}^{25}=-21.1(\mathrm{c}=1, \mathrm{EtOH}) .{ }^{1} \mathrm{H}$ NMR $\left(300 \mathrm{MHz}, \mathrm{CDCl}_{3}\right) \delta 8.05(1 \mathrm{H}, \mathrm{d}, J=8.3 \mathrm{~Hz}), 8.0-$ $7.9(2 \mathrm{H}, \mathrm{m}), 7.82(1 \mathrm{H}, \mathrm{d}, J=7.2 \mathrm{~Hz}), 7.6-7.4(3 \mathrm{H}, \mathrm{m}), 5.89(1 \mathrm{H}, \mathrm{q}, J=6.3 \mathrm{~Hz}), 2.61(1 \mathrm{H}$, br s); ${ }^{13} \mathrm{C}$ NMR (75 MHz, $\left.\mathrm{CDCl}_{3}\right) \delta 133.6,131.0,130.1,129.9,129.0,126.8,125.9,125.8$, $125.2,124.8\left(\mathrm{q}, J_{C-F}=284 \mathrm{~Hz}\right), 122.7,74.6\left(\mathrm{q}, J_{C-F}=32.0 \mathrm{~Hz}\right) ; \mathrm{MS}(\mathrm{EI}) \mathrm{m} / z 226\left(\mathrm{M}^{+}, 54\right)$, 157 (81), $129(100)$.

\section{2,2,2-Trifluoro-1-[1-(2-methylnaphthyl)]ethanol (3c)}

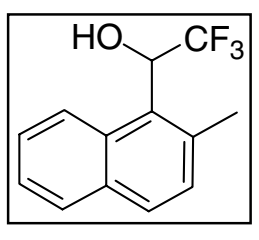

Carbinol 3c was prepared according the general procedure described for 3a using $i$-Pr-COMA $(0.5 \mathrm{mmol})$ (from $i-\mathrm{Pr}_{2} \mathrm{Mg}$ and diamine 1f) and the corresponding trifluoromethyl ketone $(60 \mathrm{mg}, 0.25 \mathrm{mmol})$. The product was purified by silica gel column chromatography $\left(10 \rightarrow 20 \% \mathrm{Et}_{2} \mathrm{O}\right.$ in hexanes) to give 4-77 as a colourless oil ( $58 \mathrm{mg}, 95 \%$, er $=7: 93$ ). The enantiomeric ratio of the product was determined by chiral phase HPLC (ChiralCel-OD, 10\% isopropanol in hexanes, 1.0 $\mathrm{mL} / \mathrm{min} R: 9.2 \mathrm{~min}, S: 23.8 \mathrm{~min}) .[\alpha]_{\mathrm{D}}{ }^{25}=+36.1\left(\mathrm{c}=1.07, \mathrm{CHCl}_{3}\right) ;$ Lit. $^{6}(R$-isomer $),[\alpha]_{\mathrm{D}}{ }^{25}$ $=-36\left(\mathrm{c}=0.634, \mathrm{CHCl}_{3}\right) .{ }^{1} \mathrm{H}$ NMR $\left(300 \mathrm{MHz}, \mathrm{CDCl}_{3}\right) \delta 8.68(1 \mathrm{H}, \mathrm{br} \mathrm{s}), 7.8-7.7(2 \mathrm{H}, \mathrm{m})$, 7.6-7.4 (2H, m), $7.30(1 \mathrm{H}, \mathrm{d}, J=8.4 \mathrm{~Hz}), 5.89(1 \mathrm{H}, \mathrm{br} \mathrm{s}), 2.76(1 \mathrm{H}, \mathrm{br} \mathrm{s}), 2.57(3 \mathrm{H}, \mathrm{br} \mathrm{s})$;

\footnotetext{
${ }^{12}$ Bucciarelli, M.; Fomi, A.; Moretti, I.; Torre, G. Synthesis, 1983, 897-899.
} 
${ }^{13} \mathrm{C}$ NMR (75 MHz, $\mathrm{CDCl}_{3}$ ) $\delta 136.3$ (br), 133.2 (br), 131.8 (br), 130.1 (br), 129.0 (br), 128.6 (br), $126.3(\mathrm{br}, 2 \mathrm{C}), 125.4\left(\mathrm{q}, J_{C-F}=284 \mathrm{~Hz}\right) 125.1,70.9(\mathrm{~m}), 21.1$; MS (EI) $\mathrm{m} / z 240$ $\left(\mathrm{M}^{+}, 60\right), 171(100), 143(84), 128(92)$.

\section{2,2,2-Trifluoro-1-(2,4,6-trimethylphenyl)ethanol (3d)}

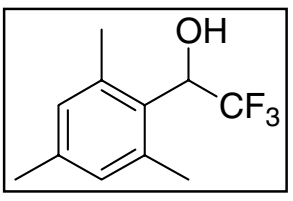

Carbinol 3d was prepared according the general procedure described for 3a using $i$-Pr-COMA $(0.5 \mathrm{mmol})$ (from $i$ - $\operatorname{Pr}_{2} \mathrm{Mg}$ and diamine 1f) and the corresponding trifluoromethyl ketone (61 mg, 0.27

$\mathrm{mmol})$. The product was purified by silica gel column chromatography $\left(10 \% \mathrm{Et}_{2} \mathrm{O}\right.$ in hexanes) to give $\mathbf{3 d}$ as a colourless oil $(55 \mathrm{mg}, 89 \%$, er $=3: 97)$. The enantiomeric ratio of the product was determined by chiral phase HPLC (ChiralCel-OD, 5\% isopropanol in hexanes, $1.0 \mathrm{~mL} / \mathrm{min} R: 10.1 \mathrm{~min}, S: 13.7 \mathrm{~min}) .[\alpha]_{\mathrm{D}}{ }^{25}=+26.64\left(\mathrm{c}=1.22, \mathrm{CHCl}_{3}\right)$; Lit. $^{6}$ $(R$-isomer $),[\alpha]_{\mathrm{D}}{ }^{25}=-30\left(\mathrm{c}=0.544, \mathrm{CHCl}_{3}\right) .{ }^{1} \mathrm{H} \mathrm{NMR}\left(300 \mathrm{MHz}, \mathrm{CDCl}_{3}\right) \delta 6.86(2 \mathrm{H}, \mathrm{s})$, $5.51(1 \mathrm{H}, \mathrm{q}, J=8.1 \mathrm{~Hz}), 2.42(7 \mathrm{H}, \mathrm{br} \mathrm{s}), 2.25(3 \mathrm{H}, \mathrm{s}) ;{ }^{13} \mathrm{C} \mathrm{NMR}\left(75 \mathrm{MHz}, \mathrm{CDCl}_{3}\right) \delta 138.8$, 138.2 (br), $131.0(\mathrm{br}), 126.9,125.6\left(\mathrm{q}, J_{C-F}=283 \mathrm{~Hz}\right), 70.2\left(\mathrm{q}, J_{C-F}=32.2 \mathrm{~Hz}\right), 20.9(3 \mathrm{C})$; MS (EI) m/z $226\left(\mathrm{M}^{+}, 54\right), 157$ (81), 129 (100).

\section{2,2,2-Trifluoro-1-(9-anthryl)ethanol (3e)}

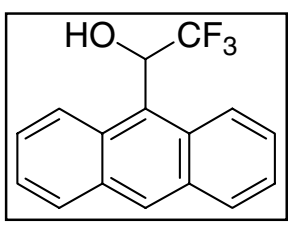

Carbinol 3e was prepared according the general procedure described for 3a using $i$-Pr-COMA $(0.5 \mathrm{mmol})$ (from $i$ - $\operatorname{Pr}_{2} \mathrm{Mg}$ and diamine 1f) and the corresponding trifluoromethyl ketone (72 mg, 0.26 mmol). The ketone was introduced directly to the reaction as a solid. The product was purified by silica gel column chromatography $\left(10 \rightarrow 20 \% \mathrm{Et}_{2} \mathrm{O}\right.$ in hexanes) to give $\mathbf{3 d}$ as a 
pale yellow solid $(69 \mathrm{mg}, 95 \%$, er $=2: 98)$. The enantiomeric ratio of the product was determined by chiral phase HPLC (ChiralCel-OD, 10\% isopropanol in hexanes, 1.0 $\mathrm{mL} / \mathrm{min} R: 12.1 \mathrm{~min}, S: 29.2 \mathrm{~min}) .[\alpha]_{\mathrm{D}}{ }^{25}=+28.6\left(\mathrm{c}=1.05, \mathrm{CHCl}_{3}\right) ;$ Lit. $^{6}(S$-isomer $)$, $[\alpha]_{\mathrm{D}}{ }^{25}=+31\left(\mathrm{c}=1.015, \mathrm{CHCl}_{3}\right) .{ }^{1} \mathrm{H}$ NMR $\left(300 \mathrm{MHz}, \mathrm{CDCl}_{3}\right) \delta 8.94(1 \mathrm{H}, \mathrm{br} \mathrm{s}), 8.52(1 \mathrm{H}$, s), $8.12(1 \mathrm{H}, \mathrm{br} \mathrm{s}), 8.01(2 \mathrm{H}, \mathrm{br} \mathrm{d}, J=8.3 \mathrm{~Hz}), 7.6-7.4(4 \mathrm{H}, \mathrm{m}), 6.63(1 \mathrm{H}, \mathrm{q}, J=8.0 \mathrm{~Hz})$, $2.90(1 \mathrm{H}, \mathrm{br} \mathrm{s}) ;{ }^{13} \mathrm{C}$ NMR (75 MHz, $\left.\mathrm{CDCl}_{3}\right) \delta 131.7$ (br), 130.7 (br), 129.2 (br), 127.3 (br, 2C), $126.2(\mathrm{br}), 125.2\left(\mathrm{q}, J_{C-F}=284 \mathrm{~Hz}\right), 124.9(\mathrm{br}, 2 \mathrm{C}), 123.7,70.0\left(\mathrm{q}, J_{C-F}=32.8 \mathrm{~Hz}\right)$; MS (EI) $m / z, 276\left(\mathrm{M}^{+}, 54\right), 207$ (65), 178 (100).

\section{1,1,1-Trifluoro-oct-3-yn-2-ol (3f)}

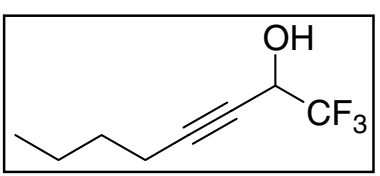

Alcohol 3f was prepared according the general procedure described for 3a using $i$-Pr-COMA $(0.5 \mathrm{mmol})$ (from $i$ - $\mathrm{Pr}_{2} \mathrm{Mg}$ and diamine 1f) and the corresponding trifluoromethyl ketone $(47 \mathrm{mg}, 0.29 \mathrm{mmol})$. The product was purified by silica gel column chromatography $\left(10 \% \mathrm{Et}_{2} \mathrm{O}\right.$ in hexanes) to give 3f as a colourless oil $(42 \mathrm{mg}, 88 \%$, er $=61: 39)$. $[\alpha]_{\mathrm{D}}{ }^{25}=+2.5\left(\mathrm{c}=0.86, \mathrm{CHCl}_{3}\right)$; Lit. ${ }^{8}(\mathrm{~S}-$ isomer), $[\alpha]_{D}^{25}=-13.2\left(\mathrm{c}=3.1, \mathrm{CHCl}_{3}\right)$. The alcohol was derivatized to the benzoate and enantiomeric ratio of the product was determined by chiral phase HPLC (ChiralCel-OD, hexanes, $1.0 \mathrm{~mL} / \mathrm{min} R: 9.7 \mathrm{~min}, S: 10.8 \mathrm{~min}) .{ }^{1} \mathrm{H} \mathrm{NMR}\left(300 \mathrm{MHz}, \mathrm{CDCl}_{3}\right) \delta$ 4.7-4.5 (1H, m), $2.53(1 \mathrm{H}, \mathrm{d}, J=8.1 \mathrm{~Hz}), 2.23(1 \mathrm{H}, \mathrm{dt}, J=1.6,6.9 \mathrm{~Hz}), 1.6-1.3(4 \mathrm{H}, \mathrm{m}), 1.89(1 \mathrm{H}, \mathrm{t}, J$ $=7.2 \mathrm{~Hz}) ;{ }^{13} \mathrm{C}$ NMR $\left(75 \mathrm{MHz}, \mathrm{CDCl}_{3}\right) \delta 122.8\left(\mathrm{q}, J_{C-F}=282 \mathrm{~Hz}\right), 89.6,72.1,62.5\left(\mathrm{q}, J_{C-F}\right.$ $=36.2 \mathrm{~Hz}), 30.0,21.8,18.2,13.5$; MS (EI) m/z 165 ([M-Me $\left.]^{+}, 1.3\right), 147$ (23), 120 (23), $111(100)$. 